\title{
Cropping on Primocanes and Floricanes Increases Yields of Organic Raspberries in High Tunnels
}

\author{
Eric Hanson ${ }^{1}$, Brent Crain, and Joshua Moses \\ Department of Horticulture, Michigan State University, East Lansing, MI \\ 48824
}

Additional index words. floricane, primocane, multiple bay tunnels, Rubus idaeus

\begin{abstract}
Red raspberry cultivars that produce fruit on current season canes (primocanes) can produce additional fruit the following year on floricanes. The primocanefruiting raspberries 'Himbo Top', 'Joan J', and 'Polka' were grown organically in high tunnels and pruned to different floricane densities to determine the effects on fruit yield (primocane, floricane, total) and harvest times. Floricane densities were 0, 2.4, or 4.8 canes per meter of row length in 2015, and 0, 4.9, or 9.8 canes per meter in 2016 and 2017. Total yield (floricane plus primocane) was significantly greater with low floricane density $\left(17 \mathrm{t} \cdot \mathrm{ha}^{-1}\right)$ or high density $\left(19 \mathrm{t} \cdot \mathrm{ha}^{-1}\right)$ compared with no floricanes $\left(12 \mathrm{t} \cdot \mathrm{ha}^{-1}\right)$. Floricane density did not affect primocane yield or harvest times. Primocanes of 'Polka' were taller when floricanes were present, but primocanes of other cultivars were unaffected. Results indicate that producing fruit on both primocanes and floricanes (double cropping) can improve sustainable overall yields.
\end{abstract}

Demand for fresh red raspberries (Rubus idaeus) by consumers in the United States has increased dramatically in the past 10 years, mirrored by an equally dramatic increase in both foreign and domestic production. Fresh raspberry movement into U.S. markets from both foreign and domestic sources grew from 98 million pounds in 2010 to 281 million pounds in 2014 (U.S. Department of Agriculture Agricultural Marketing Service, 2018). Most fresh red raspberries in North America are grown in coastal areas of California or in Mexico using a high tunnel cultivation system (Gaskell et al., 2004; Tourte et al., 2016). High tunnels allow growers to extend harvest times and produce consistently high-quality fruit in these long-season areas (Bolda et al., 2012). High tunnels provide similar benefits in regions with colder winters and shorter growing seasons (Demchak and Hanson, 2013; Hanson et al., 2011; Yao and Rosen, 2011).

Most raspberry cultivars released in the past decade are primocane fruiting, meaning they produce fruit in the autumn from the apical nodes on current-year canes, termed "primocanes" (Keep, 1961). Primocane-fruiting cultivars provide flexibility in management and

\footnotetext{
Received for publication 3 Oct. 2018. Accepted for publication 12 Dec. 2018.

This project was funded in part by support from Michigan State University AgBioResearch, National Institute of Food and Agriculture Hatch Project MICL02483, the National Institute of Food and Agriculture (NIFA) U.S. Department of Agriculture Specialty Crops Research Initiative program (Agreement 2014-51181-22380), and grants from the Michigan State Horticulture Society and the North American Raspberry and Blackberry Growers Association.

${ }^{1}$ Corresponding author. E-mail: hansone@msu. edu.
}

fruiting times, because primocanes retained over the winter produce additional fruits the following summer from basal nodes on 2-year-old canes, termed "floricanes." The fruiting cycle repeats as new primocanes grow and produce a second crop of fruit in the autumn. Managing plants to produce fruit on both floricanes and primocanes is termed "double cropping."

Double cropping is common in longseason areas such as California because raspberry harvest times can be staggered and extended (Bolda et al., 2012). In areas with shorter growing seasons, raspberries grown in the open field are typically managed for primocane fruiting only, which lowers pruning, training, and trellising costs (Bushway et al., 2008). The view that floricane fruit are lower in quality than primocane fruit (Bushway et al., 2008) may also discourage growers from double cropping, even though fruit quality differences likely vary based on cultivar and seasonal weather differences (Harshman et al., 2014). In a shorter-season location in Illinois, double cropping several older cultivars doubled yields, compared with primocane-only fruiting (Skirvin and Otterbacher, 1979). In Michigan, double cropping the cultivar Heritage increased total yield only slightly over primocane-only fruiting (Hanson et al., 2011). How newer raspberry cultivars respond to double cropping is not known.

Floricane density likely affects fruit yield and quality, but optimal densities in doublecropped plants in short-season areas are not known. Twelve to 15 floricanes per linear meter of row are recommended for double cropping in California high tunnels (Bolda et al., 2012). For floricane-fruiting cultivars in short-season regions, 9 to 15 floricanes per meter of row are recommended (Bushway et al., 2008), and retaining more canes tends to increase yield but reduce fruit quality (Gundersheim and Pritts, 1991; Vanden Heuvel et al., 2000). Because floricanes compete with primocanes for light and perhaps photosynthates (Fernandez and Pritts, 1993), retaining more floricanes in double-cropped plants may reduce subsequent primocane yields.

High-tunnel raspberry production has not been widely adopted in short-season states in the Midwest and Northeast United States, even though regional high tunnel production recommendations have been developed (Pritts et al., 2017). The slow adoption likely reflects concerns over the high initial investment cost and the additional knowledge and labor that is required to manage the high tunnels and plants, as well as the recent establishment of the exotic pest spotted wing drosophila (Drosophila suzukii) (Conner and Demchak, 2018). The purpose of this study was to compare the yield potential and harvest periods of double-cropped primocane-fruiting raspberries managed with varying floricane densities in a short-growing-season area. The study was conducted in high tunnels to enhance plant vigor and managed organically because organic berry prices are generally higher than conventional prices (Tourte et al., 2016).

\section{Materials and Methods}

The study was conducted in three $61 \times$ $8 \times 4.9$ m (length $\times$ width $\times$ height) interconnected high tunnel bays (Haygrove Tunnels Ltd., Redbank, UK) at the Michigan State University Horticulture Teaching and Research Center in East Lansing, MI (lat. $42.75^{\circ} \mathrm{N}$, long. $\left.84.47^{\circ} \mathrm{W}\right)$. The soil was a Spinks loam sand (mixed, mesic Psammentic Hapludalf). Each bay was planted in 2010 with one row each of the primocane-fruiting red raspberries 'Himbo Top', 'Joan J', and 'Polka', arranged randomly so that each bay served as a replication. Initial spacing was $45 \mathrm{~cm}$ apart in the row, but plants had developed into a continuous hedgerow by 2015 when the study started. Rows were $2.4 \mathrm{~m}$ apart and irrigated with two drip tubes with emitters every $0.6 \mathrm{~m}$ that delivered $2.3 \mathrm{~L} \cdot \mathrm{h}^{-1}$. Plants were usually watered once per day for $1 \mathrm{~h}$ or twice per day on warmer days.

Tunnels were covered with Luminance THB polyethylene film (BPI.Visqueen Horticultural Products, Stockton-on-Tees, UK) from late April or early May until the middle of October. The polyethylene film was pushed up onto the lower portions of the tunnel hoops during warm periods in the summer to increase ventilation. Additional polyethylene film was secured to the leg posts in late September to reduce ventilation and retain heat.

Plants were fertilized each March with 440 $\mathrm{kg} \cdot \mathrm{ha}^{-1}$ of $10-2-8 \mathrm{NOP} / \mathrm{OMRI}$ approved fertilizer (McGeary Organics, Lancaster, PA), and from June through September with twiceweekly applications of a 2-2-0 fish hydrolysate (Schafer Fisheries, Thomson, IL) injected through the trickle irrigation system. The total 
amount of $\mathrm{N}$ applied per year approximated $100 \mathrm{~kg} \cdot \mathrm{ha}^{-1}$. A composite sample of 30 leaves was collected in August from each row and analyzed for essential elements (A and L Laboratories, Ft. Wayne, IN).

Weeds within the rows were removed by hand twice during the season. Aisles between rows were cultivated with a rototiller two or three times per year. In 2017, weedbarrier fabric (DeWitt, Sikeston, MO) was placed in some row aisles to help suppress weeds.

Plants were monitored for insects and damage. Spotted wing drosophila (Drosophila suzukii) adults were monitored by trapping. Plants were treated with NOP/OMRI approved insecticides (spinosin, pyrethrum) when insect populations reached damaging levels or management thresholds. To quantify plant parasitic nematodes, a composite sample consisting of 10 soil cores was collected in Sept. 2017 from beneath the plants in each row. Nematodes were identified and quantified by the MSU Diagnostic Services laboratory using standard centrifugation/ flotation methods. Two composite samples of young leaf tissue were collected from each plot in Sept. 2017 and tested using enzyme-linked immunoassay for tobacco ringspot virus (TRSV) and tomato ringspot virus (TomRSV).

Three floricane density treatments (none, lower, higher) were imposed on the same $6.1 \mathrm{~m}$ long adjacent sections in each row. Buffer sections were left on the ends of each row, but the plots were not separated by buffer plants. Treatments were imposed in Apr. 2015, 2016, and 2017 by retaining specified numbers of healthy canes greater than $1 \mathrm{~m}$ tall. In $2015,0,2.4$, and 4.8 canes per $m$ of row were kept in the none, lower, and higher treatments, respectively. In 2016 and 2017, 0, 4.9, or 9.8 canes per $m$ were kept. Fewer canes were retained in 2015 because of winter cold injury. Removed floricanes were cut at ground level. Retained canes were tied in the spring to a V-trellis with two or three wires on the outside of each row. This allowed primocanes to grow in the middle between the secured floricanes. When floricane harvest concluded, the canes were removed and primocanes were secured to the outer wires.

All ripe fruit were picked by hand from each $6.1 \mathrm{~m}$ long plot area. Floricane fruit were harvested on an average of 11 dates per year between $\approx 20$ June and 20 July. Primocane fruit and were picked an average of 20 times per year between 1 Aug. and 14 Oct. Harvest intervals were $2-3$ d during warm weather (generally in June, July, and August) and 3-5 d when temperatures were cooler in September and October. Total fruit weight per plot was recorded on each date. Due to time constrains, marketable and nonmarketable fruit were not quantified separately. The relative earliness of harvest was determined by calculating the number of days after 20 June (floricane harvest) and 1 Aug. (primocane harvest) when $10 \%$ of the total yield for each individual plot was exceeded.
Cane growth was assessed each spring before pruning on 10 randomly selected floricanes per plot. Measurements included total cane length, length that fruited the previous autumn (determined by remnants of fruiting laterals and fruit), total number of nodes and nodes that fruited the previous autumn.

The experimental design was a split plot. The main plot was cultivar, arranged randomly within each of the three tunnels (three replications). The pruning treatments served as subplots, arranged randomly within each of the nine main plots. Data were analyzed using SAS v9.4 (SAS Institute Inc., Cary, NC). The effects of treatments on growth, development, and yield were analyzed by analysis of variance using PROC MIXED. Where variances were unequal (based on Levene's test and plots of residuals), a model with heterogenous variances was fit. When interactions were significant, tests of simple effects were carried out by slicing. Means were separated using Tukey's honestly significant differences. All statistical tests for significance were conducted at $P \leq 0.05$. The response variable floricane yield was square-root transformed to normalize the distribution.

\section{Results}

Across all years and cultivars, total fruit yield (primocane plus floricane) increased with greater floricane density, and averaged $17.8,25.2$, and $27.4 \mathrm{~kg} / \mathrm{plot}$ for the none (control), lower, and higher floricane density treatments, respectively $(P \leq 0.05)$. Significant year $\times$ cultivar interactions were identified when primocane and floricane yield data were analyzed separately, prompting us to carry out tests of simple effects (Fig. 1). Primocane fruit yields were unaffected by floricane density treatments in any year or cultivar. Floricane fruit yields were generally highest under the higher floricane density treatment $(P \leq 0.05)$. The exception was in 2017, when the floricane yields from 'Polka' and 'Joan J' were similar between higher and lower density treatments (Fig. 1). Overall total yields across density treatments and years were 26, 22, and $21 \mathrm{~kg} / \mathrm{plot}$ for 'Himbo Top', 'Polka', and 'Joan J', respectively.

Earliness-of-harvest data were analyzed by year because of significant year $\times$ cultivar interactions. Cultivar $\times$ floricane density interactions were subsequently investigated and determined to be ordinal (noncrossing), allowing us to evaluate main effects. Floricane density (lower or higher) did not affect the earliness of floricane harvest in any year. In each year, floricane harvest occurred earlier $(P \leq 0.05)$ for 'Joan J' (22 June, 3-year mean) than for 'Himbo Top' (30 June) or 'Polka' (1 July). The earliness of primocane harvest also was unaffected by floricane density; means across all years and cultivars were 3 Sept. (none [control]) and 4 Sept. (lower, higher). Each cultivar differed significantly in earliness of primocane harvest: 'Joan J' was the earliest (29 Aug., 3-year mean), followed by 'Polka' (2 Sept.) and 'Himbo Top' (8 Sept.).

We examined cultivar $\times$ year interactions in the primocane length data and found them to be ordinal. Across years, floricane density significantly affected the length of 'Polka' primocanes, but not those of 'Joan J' or 'Himbo Top'. Over 3 years, 'Polka' primocanes were significantly shorter $(183 \mathrm{~cm})$ when no floricanes were retained than when lower or higher floricane numbers were retained $(200 \mathrm{~cm})$. Primocane length differed significantly for each cultivar. Over 3 years and across floricane densities, 'Himbo Top' produced the tallest canes $(217 \mathrm{~cm})$, followed by 'Polka' (194 cm) and 'Joan J' $(182 \mathrm{~cm})$.

We used tests of simple effects to investigate significant cultivar $\times$ year and floricane density $\times$ year interactions in the node-development data. Floricane densities had effects on the number of nodes per cane and the percentage of nodes that fruited in the fall on primocanes, but these effects were not consistent across years or among cultivars. Lower floricane density resulted in significantly more nodes than higher densities only in 'Joan J' in 2015 and in 'Himbo Top' in 2016. Both lower and higher floricane densities increased the percent of nodes that fruited in 'Polka' only in 2016. 'Himbo Top' primocanes consistently produced more nodes (42 per cane, 3-year mean) than 'Polka' (36) or 'Joan J' (35). The percentage of nodes that fruited in the fall was significantly lower in 'Himbo Top' (34\%, 3-year mean) than in either 'Joan J' (41\%) or 'Polka' (44\%).

'Joan J' and 'Himbo Top' plants were severely infected with TomRSV in 2017. Of the 18 samples collected from the 'Joan J', 'Himbo Top', and 'Polka' plots, 18, 15, and 0 samples tested positive, respectively. TRSV was not detected in any samples. Soils contained high populations of virus vectoring dagger nematodes (Xiphinema americanum) in rows of 'Himbo Top' $\left(210 / \mathrm{cm}^{3} \pm 58\right)$, 'Joan J' $\left(200 / \mathrm{cm}^{3} \pm 65\right)$, and Polka $\left(311 / \mathrm{cm}^{3} \pm 69\right)$.

Leaf nutrient levels from composite samples collected across pruning treatments were generally within optimal ranges proposed by Bushway et al. (2008). Sulfur was the only nutrient consistently below optimal levels (3-year mean: $0.17 \%$, optimal range: $0.4 \%$ to $0.6 \%$ ). Potassium levels were marginally deficient in 2016 and 2017 (1.44\% both years) compared with the optimal range of $1.5 \%$ to $2.5 \%$.

\section{Discussion}

Retaining floricanes increased total yields across cultivars by $48 \%$ (lower floricane density) or $58 \%$ (higher density) compared with removal of all floricanes (Fig. 1). Total yield increases were the result of floricane production because primocane fruiting was unaffected by floricane density. Total annual yields were equivalent to 12,17 , and $19 \mathrm{t} \cdot \mathrm{ha}^{-1}$ in the none (control), lower, and higher density treatments, respectively. These yields were higher than open-field yields reported in other studies (Hanson et al., 2005; Skirvin 


\section{Primocanes $\square$ Floricanes}
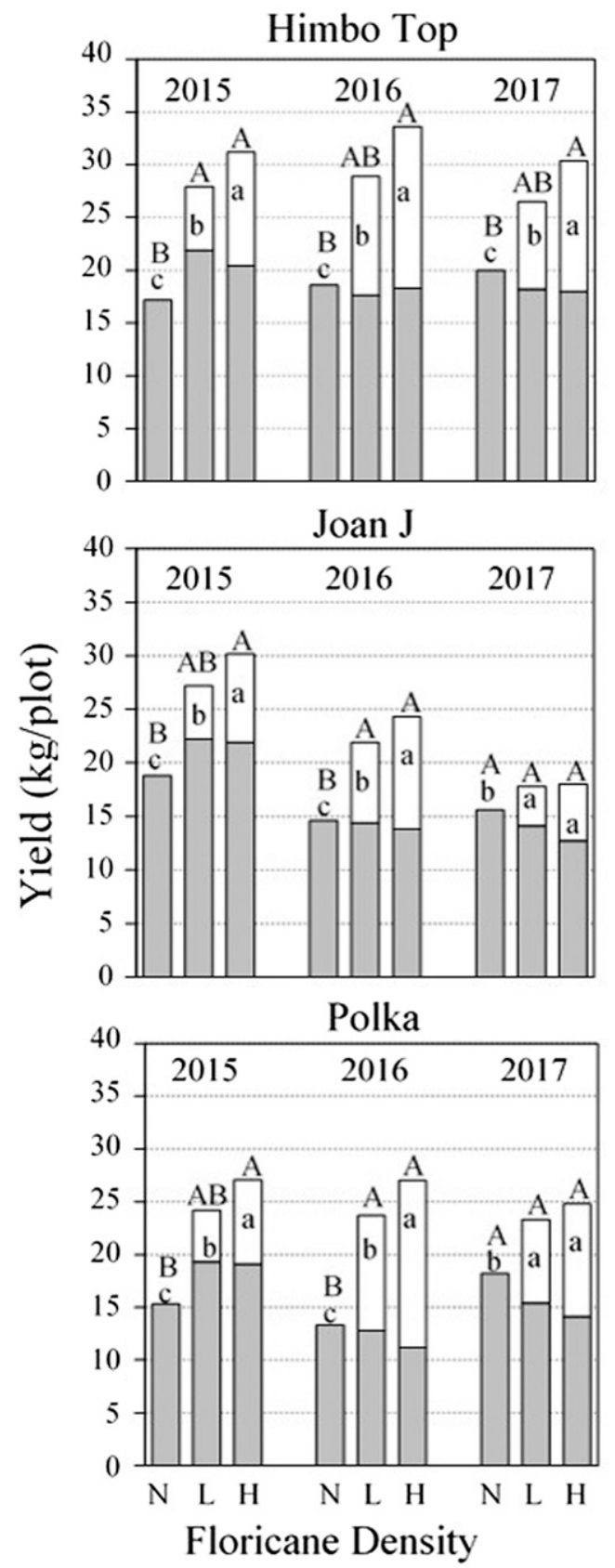

$\mathrm{N}=$ no Floricanes, $\mathrm{L}=$ lower Floricane density, $\mathrm{H}=$ higher Floricane density

Fig. 1. Effect of floricane density on double cropping yield of three raspberry cultivars. Lower case letters designate significant difference between floricane yields, and capital letters designate significant differences between total yields within years and cultivars $(\mathrm{n}=3, P \leq 0.05)$.

and Otterbacher, 1979) but lower than reported yields of raspberries grown conventionally in tunnels (Hanson et al., 2011) in this region.

The highest floricane density tested here ( 9.8 per $\mathrm{m}$ ) was low compared with densities of 10 to 16 per meter recommended for fieldgrown raspberries (Bushway et al., 2008; Crandall, 1995). Higher floricane densities tended to increase floricane yields over lower densities, but retaining twice as many floricanes
Sønsteby et al., 2018). Average berry weights were not measured in the present study. Optimal cane density is expected to vary with cultivar, management, and site conditions. Results of this study suggest that optimal floricane density for 'Joan J' and 'Polka' may be lower than for 'Himbo Top'.

The presence of floricanes did not reduce primocane growth or berry production (Fig. 1). Because floricanes can shade developing primocanes, retention of floricanes was expected to lengthen primocane internodes and increase their final lengths, as observed with raspberries (Sønsteby et al., 2018; Wright and Waister, 1982) and blackberries (Strik et al., 2012). 'Polka' primocanes were $\approx 10 \%$ taller when floricanes were present, but the heights of 'Himbo Top' or 'Joan J' primocanes were unaffected by floricanes. The use of a V-trellis to separate the floricanes from the primocanes may have minimized shading in this study.

Cultivars best suited for double cropping tend to produce tall canes with high node numbers so that they retain adequate length and node numbers for high floricane yields during the subsequent season. The most productive cultivar in this study ('Himbo Top') also produced the tallest canes with the most nodes. In contrast, 'Joan J' produced shorter primocanes with fewer nodes and a higher percentage of nodes that fruited in the fall. This may partly explain why 'Joan J' produced the lowest floricane yields of the three cultivars.

The cultivars in the trial are considered either early ('Joan J', 'Polka') or early midseason ('Himbo Top'), based on the beginning of the primocane harvest season (Hanson et al., 2018). Earlier-fruiting cultivars are popular in short-growing-season regions because adequate yields can be picked before cold weather stops primocane fruiting. However, very early primocane fruiting cultivars may not be best choices for double cropping because their floricane fruiting potential is limited. Early fruiting types tend to produce shorter primocanes because growth ceases early in the summer when floral development begins (Keep, 1988). Because nodes are produced at a constant rate (Jennings and Dale, 1982), early fruiting cultivars are also expected to produce fewer nodes for floricane production during the subsequent season. The most productive cultivars for a specific region would produce early enough for acceptable primocane yields but not so early as to limit subsequent floricane yields. High tunnels tend to prolong the growing season and fall harvest period (Demchak and Hanson, 2013) and may enable growers to choose somewhat later primocane-fruiting cultivars for double cropping in short season locations. Production times also need to match desired marketing periods for each grower.

Overall yield and vigor of 'Joan J' and 'Himbo Top' plants may have been affected by TomRSV infection, particularly late in the study. Plants were tested in 2017 for the presence of TRSV and TomRSV because some plots of 'Joan J' exhibited an apparent 
decline in vigor and increase in crumbly fruit, both symptoms of virus infection (Stace-Smith and Converse, 1987). TomRSV was detected in all plots of 'Joan J' and nearly all plots of 'Himbo Top' but no plots of 'Polka'. Dagger nematodes that vector TomRSV were abundant throughout the trial area. The response of raspberry cultivars to TomRSV infection varies from severe to none (Stace-Smith and Converse, 1987), but it is not clear why 'Polka' plants in soils infested with the nematode vector appeared to be clean of virus. No reports could be found describing 'Polka' as resistance to dagger nematodes or TomRSV.

The organic fertilization and pest management approaches appeared to be effective during this trial. On the basis of leaf analyses, $\mathrm{S}$ was the only nutrient consistently below desired levels, although leaf K was marginally deficient during the last two seasons. These plants were fertilized with similar materials before the beginning of this trial and grew and produced well (Hanson et al., 2016). The prevalence of pest and beneficial insects in these tunnels was described earlier (Leach and Isaacs, 2018). Spotted wing drosophila was a serious pest infesting ripening fruits and rendering them nonmarketable. In this location, adult flies are usually abundant from the second half of the floricane fruiting season to the end of the primocane fruiting season (Leach and Isaacs, 2018; Leach et al., 2016). Floricane fruits are generally easier to protect from this pest than primocane fruits that mature later in the season when fly populations are high. A benefit of tunnels is that the structure can be used to support fine mesh, exclusion netting, which has been shown to reduce fruit infestation levels (Leach et al., 2016).

These results indicate that production on primocane-fruiting red raspberries can be increased by fruiting on both primocanes and floricanes (double cropping). Higher floricane densities increased floricane yields, although yield did not increase in proportion to floricane numbers. Retaining floricanes did not affect primocane yields or alter harvest times. Because this was only a 3-year study, longer-term effects are not known.

\section{Literature Cited}

Bolda, M., M. Gaskell, E. Mitcham, and M. Cahn. 2012. Fresh market caneberry production manual. Univ. California Agr. Natural Resources Publ. 3525.

Bushway, L.P., M. Pritts, and M. Handley. 2008. Raspberry and blackberry production guide for the Northeast, Midwest, and Eastern Canada. (Natural Resource Agr. Eng. Serv. NRAES-35, Ithaca, NY).

Conner, D.S. and K. Demchak. 2018. Farmer perceptions of tunnels for berry production: Management and marketing implications. HortTechnology 28:706-710.

Crandall, P.C. 1995. Pruning and training red raspberries, p. 114-122. In: Bramble production: The management and marketing of raspberries and blackberries. Food Products Press, Binghamton, NY.

Demchak, K. and E. Hanson. 2013. Small fruit production in high tunnels in the U.S. Acta Hort. 987:41-44.

Fernandez, G. and M. Pritts. 1993. Growth and source-sink relationships in 'Titan' raspberry. Acta Hort. 352:151-158.

Gaskell, M., D. Cantliffe, P. Stoffella, and N. Shaw. 2004. Field tunnels permit extended season harvest of small fruits in California. Acta Hort. 659:425-430.

Gundersheim, N. and M. Pritts. 1991. Pruning practices affect yield, yield components, and their distribution in 'Royalty' purple raspberry. J. Amer. Soc. Hort. Sci. 116:390-395.

Hanson, E., B. Crain, and D. Brown Rytlewski. 2018. Primocane-fruiting red raspberry cultivar evaluation in high tunnels. J. Amer. Pomol. Soc. 72:122-127.

Hanson, E., S. Berkheimer, A. Schilder, R. Isaacs, and S. Kravchenko. 2005. Raspberry variety performance in southern Michigan. HortTechnology 15:716-721.

Hanson, E., T. Marks, and R. Isaacs. 2016. Organic high tunnel production of raspberries in a humid region. Acta Hort. 1133:259-262.

Hanson, E., M. Von Weihe, A. Schilder, A. Chanon, and J. Scheerens. 2011. High tunnel production of floricane- and primocane-fruiting raspberries. HortTechnology 21:412-418.

Harshman, J., K. Lewers, W. Jurick, and C. Walsh. 2014. Breeding selection efficiency for raspberry postharvest shelf life affected by storage temperature and harvest season. Euphytica 199:283-292.

Jennings, D. and A. Dale. 1982. Variation in the growth habit of red raspberries with particular reference to cane height and node production. J. Hort. Sci. 57:197-204.
Keep, E. 1961. Autumn-fruiting in raspberries. J. Hort. Sci. 36:174-185.

Keep, E. 1988. Primocane fruiting raspberries; a review. J. Hort. Sci. 63:1-18.

Leach, H. and R. Isaacs. 2018. Seasonal occurrence of key arthropod pests and beneficial insects in Michigan high tunnel and field grown raspberries. J. Environ. Entomol. 47: 567-574.

Leach, H., S. Van Timmeren, and R. Isaacs. 2016. Exclusion netting delays and reduces Drosophila suzukii (Diptera: Drosophilidae) infestation in raspberries. J. Econ. Entomol., doi: 10.1093/ jee/tow157.

Pritts, M., L. McDermott, K. Demchak, E. Hanson, C. Weber, A. Both, G. Loeb, and C. Heidenreich. 2017. High tunnel raspberries and blackberries. $<$ http://www.hort.cornell.edu/fruit/pdfs/hightunnel-brambles.pdf $>$.

Skirvin, R. and A. Otterbacher. 1979. Effects of single and double cropping on yields of fall bearing raspberries. Fruit Var. J. 33:144148.

Sønsteby, A., U. Roos, and O. Heide. 2018. Effects of biennial cropping and controlled shoot density on yield performance and fruit quality in red raspberry (Rubus idaeus L.). J. Hortic. Sci. Biotechnol., doi: 10.1080/14620316.2018.1478678.

Stace-Smith, R. and R. Converse. 1987. Tomato ringspot virus in Rubus. In: R.H. Converse (ed.). Virus disease of small fruit. USDA Agr. Res. Serv. Agricultural Handbook No. 631.

Strik, B., J. Clark, C. Finn, and G. Buller. 2012. Management of primocane-fruiting blackberry: Impacts on yield, fruiting season, and cane architecture. HortScience 47:593-598.

Tourte, L., M. Bolda, and K. Klonsky. 2016. The evolving fresh market berry industry in Santa Cruz and Monterey counties. Calif. Agr. 70:107-115, doi: 10.3733/ca.2016a0001.

U.S. Department of Agriculture Agricultural Marketing Service. Specialty crops retail report. 2018. 22 Mar. 2018. <https://marketnews.usda. gov/mnp/fv-home $>$.

Vanden Heuvel, J., A. Sullivan, and J. Proctor. 2000. Trellising system and cane density affect yield and fruit quality of red raspberry. HortScience 35:1215-1219.

Wright, C. and P. Waister. 1982. Within plant competition in the red raspberry. I. primocane growth. J. Hort. Sci. 57:437-442.

Yao, S.R. and C.J. Rosen. 2011. Primocanefruiting raspberry production in high tunnels in a cold region of the upper Midwestern United States. HortTechnology 21:429-434. 